\title{
NRIP3 Gene
}

National Cancer Institute

\section{Source}

National Cancer Institute. NRIP3 Gene. NCI Thesaurus. Code C126614.

This gene may play a role in proteolysis or nuclear receptor activity. 